\title{
Myxozoan pathogens of Malaysian fishes cultured in ponds and net-cages
}

\author{
Cs. Székely ${ }^{1, *}$, F. Shaharom-Harrison ${ }^{2}$, G. Cech $^{1}$, K. Mohamed ${ }^{2}$, K. Molnár ${ }^{1}$ \\ ${ }^{1}$ Veterinary Medical Research Institute, Hungarian Academy of Sciences, PO Box 18, 1581 Budapest, Hungary \\ ${ }^{2}$ Institute of Tropical Aquaculture, University Malaysia Terengganu, 2130 Kuala Terengganu, Terengganu, Malaysia
}

\begin{abstract}
We describe new myxosporean species from Malaysian fishes cultured in pond farms and net-cages. Myxobolus omari sp. nov. and M. leptobarbi sp. nov. were found in the muscles of Pangasianodon hypophthalmus and Leptobarbus hoevenii, respectively, while plasmodia and spores of Thelohanellus zahrahae sp. nov. and Henneguya daoudi sp. nov. were detected in the gills of Barbonymus gonionotus and Trichogaster trichopterus, respectively. Plasmodia and spores found in these fishes differed from the known myxosporean species in respect of their morphology, tissue tropism and 18S rDNA structure. No major pathological changes were found, but in the future these species might pose a potential threat to more intensified fish culture.
\end{abstract}

KEY WORDS: Myxozoa - New Myxobolus spp. - New Thelohanellus sp. · New Henneguya sp. Morphology $\cdot$ Histology $\cdot$ Tissue tropism $\cdot$ 18S rDNA

Resale or republication not permitted without written consent of the publisher

\section{INTRODUCTION}

Fish culture is a fast-developing branch of agriculture in Malaysia (Ang 1990, Ong 1993). Besides the intensive culture of fish species such as Tilapia spp., Clarias spp. and Pangasius spp. in tropical countries, the selection of endemic fishes for culture and their economic utilization are in progress. Endemic cyprinid species like Leptobarbus hoevenii, Barbonymus gonionotus and Tor tambroides are the favorite food fishes in Southeast Asia, and they are caught in freshwater rivers or lakes or cultured in ponds.

Little is known, however, about infectious and invasive agents causing damage to stocks of these fish species. In a companion paper (Székely et al. in press, this issue) we report myxozoan infections of fishes of the Tasik Kenyir water reservoir, Malaysia, and describe 5 new species. In the present paper we give an account on further studies on myxosporean infections found in cultured Malaysian fishes such as sutchi catfish Pangasianodon hypophthalmus (Sauvage, 1878), mad barb Leptobarbus hoevenii (Bleeker, 1851), Java barb Barbonymus gonionotus (Bleeker, 1850) and three spot gourami Trichogaster trichopterus (Pallas, 1770).
In this paper 4 new species, Myxobolus omari sp. nov., M. leptobarbi sp. nov., Thelohanellus zahrahae sp. nov. and Henneguya daoudi sp. nov. will be described.

\section{METHODS}

Fishes were collected from a pond fish farm (Machang, Kelantan State, Malaysia) and a net-cage fish farm in a channel south of Kuala Terengganu city, Terengganu State, Malaysia.

During a 2 wk period in April 2007 various size and age classes of 6 cultured fish species, Pangasianodon (Pangasius) hypophthalmus (sutchi catfish, patin, $\mathrm{n}=$ 10), Leptobarbus hoevenii (mad barb, jelawat, $\mathrm{n}=20$ ), Barbonymus gonionotus (Java barb, lampam jawa, $\mathrm{n}=$ 10), Trichogaster trichopterus (three spot gourami, sepat, $\mathrm{n}=5$ ), Monopterus albus (swamp eel, belut, $\mathrm{n}=$ 10) and Tilapia sp. $(\mathrm{n}=10)$, were examined for myxozoan infections in the laboratory of the Institute of Tropical Aquaculture (AQUATROP), University Malaysia Terengganu (UMT).

The investigations were aimed at studying myxosporean infections only. For a detailed description of 
the techniques of parasitological dissections and the processing of the collected material as well as for molecular methods, see a similar study on fishes of the Tasik Kenyir Water Reservoir (Székely et al. 2009, this issue).

\section{RESULTS}

Myxozoan infections were found in 4 out of the 6 fish species examined. Infection of the muscles by Мухоbolus spp. was found in 2 fish species, mad barb Leptobarbus hoevenii and sutchi catfish Pangasianodon hypophthalmus. In the muscles of the mad barb, large, elongated plasmodia of a Myxobolus sp. filled with spores were found. The plasmodia were located intracellularly in the muscle cells. Mature spores of the same species infecting the subepithelial layer of the renal tubules and the urinary ducts were frequently found also in the kidney. In the sutchi catfish, only scattered spores but no plasmodia of another Myхоbolus sp. were recorded in the muscle. Gill infection was found in 2 fish species. In the gills of Barbonymus gonionotus cysts filled with large spores of a Thelohanellus sp. were found, while in the gills of Trichogaster trichopterus plasmodia containing Henneguya sp. spores were detected. Myxobolus spp. infecting L. hoevenii and P. hypophthalmus, Thelohanellus sp. infecting B. gonionotus and Henneguya sp. from Trichogaster trichopterus proved to be new for science. Descriptions of the species found are as follows.

\section{Myxobolus omari sp. nov.}

Type host: Sutchi catfish Pangasianodon hypophthalmus (Sauvage, 1878) syn. Pangasius sutchi Fowler, 1937 (Pangasiidae). Local name: patin.

Type locality: Net-cage of a family fish farm in a channel, Kuala Terengganu, Malaysia.

Site of tissue development: Muscle cells. Plasmodia were not detected; however, dispersed spores and spores in groups located among muscle cells were isolated.

Type material: Digitized photos of syntype spores and histological sections were deposited in the parasitological collection of the Zoological Department, Hungarian Natural History Museum, Budapest, coll. no. HNHM-70087. The 18S rDNA sequence of Myхоbolus omari sp. nov. was deposited in GenBank under accession no. EU643624.

Prevalence of infection: $1 / 10$ of the 20 to $25 \mathrm{~cm}$ sized fish.

Intensity of infection: Moderate.
Etymology: The species is named after Tan Sri Omar Abdul Rahman, veterinarian, formerly the Scientific Advisor to the Prime Minister of Malaysia.

Spores: The spores (Figs. 1a,b \& 2a) were unique in shape with larger dimensions in width than in length. In frontal view they were bluntly ellipsoidal with 2 nearly equal or somewhat differing polar capsules. In
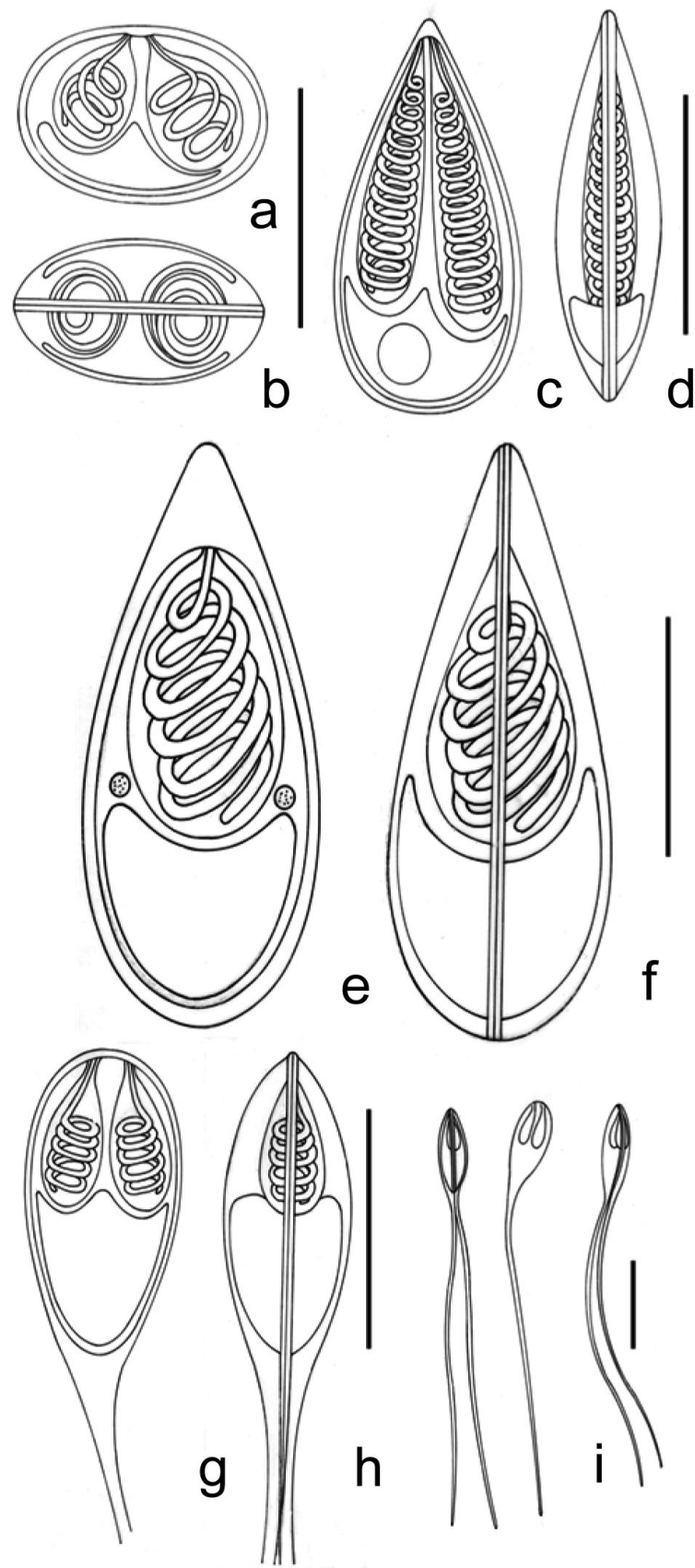

Fig. 1. Schematic illustrations of spores. Myxobolus omari sp. nov. (a) frontal and (b) upper view; $M$. leptobarbi sp. nov. (c) frontal and (d) sutural view; Thelohanellus zahrahae sp. nov. (e) frontal and (f) sutural view; Henneguya daoudi sp. nov. (g) frontal view, (h) sutural view, and (i) with caudal extensions. Scale bars $=10 \mu \mathrm{m}$ 


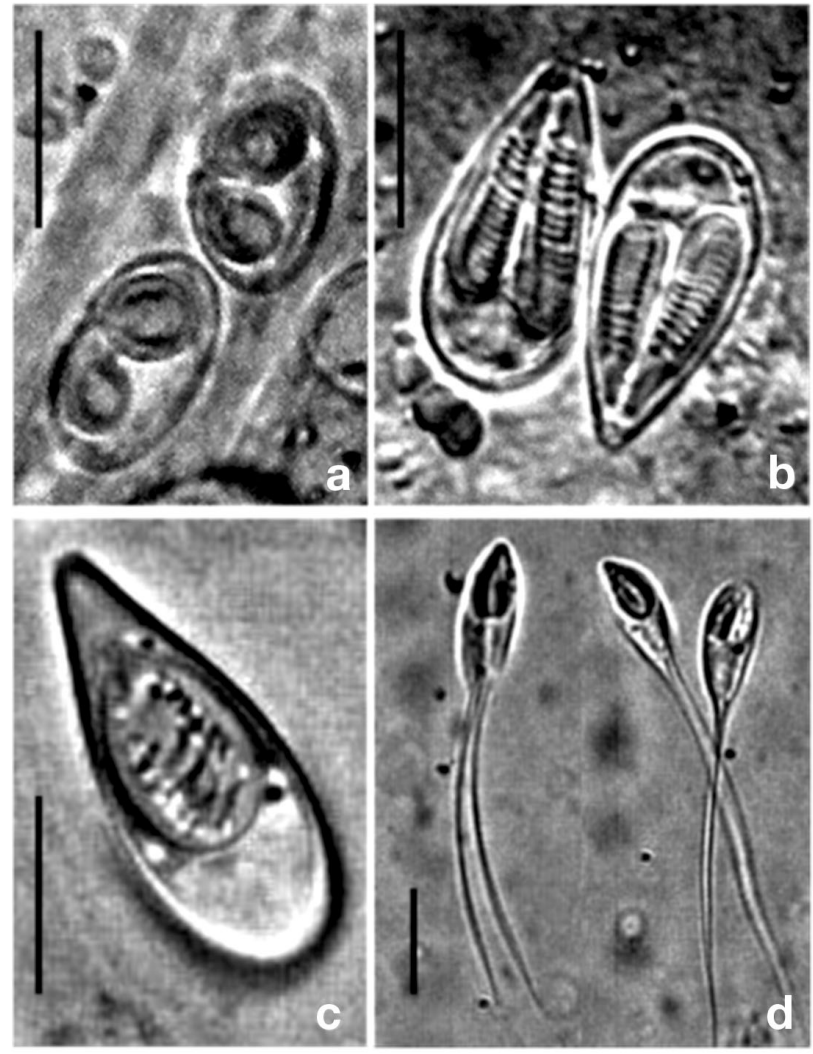

Fig. 2. Fresh spores of (a) Myxobolus omari sp. nov., (b) $M$. leptobarbi sp. nov., (c) Thelohanellus zahrahae sp. nov. and (d) Henneguya daoudi sp. nov. Scale bars $=10 \mu \mathrm{m}$

up-down position the spores were elongated ellipsoidal. The mean $( \pm \mathrm{SD})$ length of the spores was $7.9 \pm$ 0.50 (range, 7.2 to 8.8) $\mu \mathrm{m}(\mathrm{n}=50)$, width $12 \pm 0.84 \mu \mathrm{m}$ (range, 11 to 13.9$)(\mathrm{n}=50)$, thickness $5.9 \pm 0.50$ (range, 5.2 to 6.6) $\mu \mathrm{m}(\mathrm{n}=3)$. Polar capsules were drop-shaped, filling most part of the spore cavity. Larger capsules were $5.9 \pm 0.74$ (range, 4.4 to 6.6) $\mu \mathrm{m}$ long $(\mathrm{n}=50$ ) and $4.7 \pm 0.76$ (range, 4.0 to 5.3 ) $\mu \mathrm{m}$ wide $(\mathrm{n}=50)$. Smaller capsules were $5.6 \pm 0.74$ (range, 4.0 to 6.2$) \mu \mathrm{m}$ long $(\mathrm{n}=50)$ and $4.3 \pm 0.60$ (range, 3.6 to 4.9 ) $\mu \mathrm{m}$ wide. Filament coils were not clearly observable. A small, flat intercapsular process was present. Sutural edge markings were not seen. A single, very small binucleated sporoplasm with round iodinophilous vacuole was present. Mucous envelope was not found.

Molecular data: Based on the data of pairwise alignments, the species most closely related to Myxobolus omari were $M$. cerebralis and $M$. arcticus, but the values of similarity among them were only 77 and $76 \%$ (see Fig. $9 \& 10$ ). It is also visible on the phylogenetic tree that $M$. omari is next to the branch of clade containing the majority of Henneguya spp.
Histology: No plasmodia or spores were found in histological sections.

Remarks: The characteristic wide spores of this species resemble those of Myxobolus artus Akhmerov, 1960, a parasite infecting the muscles of common carp in Japan, but differ by their large polar capsules.

\section{Myxobolus leptobarbi sp. nov.}

Type host: Mad barb Leptobarbus hoevenii (Bleeker, 1851), (Cyprinidae). Local name: jelawat.

Type locality: Fish farm, Machang, Kelantan Province, Malaysia.

Site of tissue development: Muscle cells. Mature disporoblastic plasmodia were located intracellularly in muscle cells. They were elongated and up to 500 to $700 \mu \mathrm{m}$ in length. Only old plasmodia filled with spores were found. Mature spores were also frequently found in the kidney. These spores were located in large numbers embedded in the subepithelial layer of the renal tubules and urinary ducts. Spores were also found in renal ducts and macrophage centers.

Type material: Digitized photos of syntype spores and histological sections were deposited in the parasitological collection of the Zoological Department, Hungarian Natural History Museum, Budapest, coll. no. HNHM-70088. The 18S rDNA sequence of Myxobolus leptobarbi sp. nov. was deposited in GenBank under accession no. EU643623.

Prevalence of infection: $14 / 20$ in the 1st yr age group (fish 10 to $12 \mathrm{~cm}$ in size).

Intensity of infection: Moderate to severe.

Etymology: The name of the species is derived from that of its host.

Spores: Large spores (Figs. 1c \& 2b) were oval in frontal view, sharply tapering at the anterior poles. In sutural view they were spindle-shaped, sharply tapering at the anterior end (Fig. 1d). The mean $( \pm \mathrm{SD})$ length of the spores was $16 \pm 0.68$ (range, 14.8 to 17 ) $\mu \mathrm{m}(\mathrm{n}=50)$, width $8.9 \pm 0.32$ (range, 8.4 to 9.6) $\mu \mathrm{m}(\mathrm{n}=$ $50)$, thickness $5.1 \pm 0.32$ (range, 5.5 to 6.5$) \mu \mathrm{m}(\mathrm{n}=3)$. Polar capsules of different size were elongated, very long, slightly converging anteriorly. Larger capsules were $10.5 \pm 0.47$ (range, 9.9 to 11.5$) \mu m$ long $(n=50)$ and $3 \pm 0.35$ (range, 2.3 to 3.6 ) $\mu \mathrm{m}$ wide $(\mathrm{n}=50$ ). Smaller capsules were $9.9 \pm 0.72$ (range, 8.8 to 10.6) $\mu \mathrm{m}$ long $(\mathrm{n}=50)$ and $3 \pm 0.35$ (range, 2.3 to 3.6$) \mu \mathrm{m}$ wide. Thirteen to 15 filament coils arranged perpendicularly to the capsule length were wound densely in the polar capsule. No intercapsular appendix was seen. Sutural edge markings were not seen. A single, very small binucleated sporoplasm with round iodinophilous vacuole was present. Mucous envelope was not found. 
Molecular data: The 18S rDNA sequence of Myxoblus leptobarbi sp. nov. showed the closest similarity with other muscle-infecting Myxobolus species (see Figs. $9 \& 10$ ). However, the values of similarity were rather low: $87.5 \%$ to $M$. stanlii, $87.2 \%$ to $M$. pseu- dodispar, $87.5 \%$ to $M$. musculi and $87.8 \%$ to M. cyprini over a 1052 bp long alignment.

Histology: Large plasmodia of this species filled with spores were found in the muscles, located intracellularly in muscle cells (Fig. 3). In some parts of the mus-
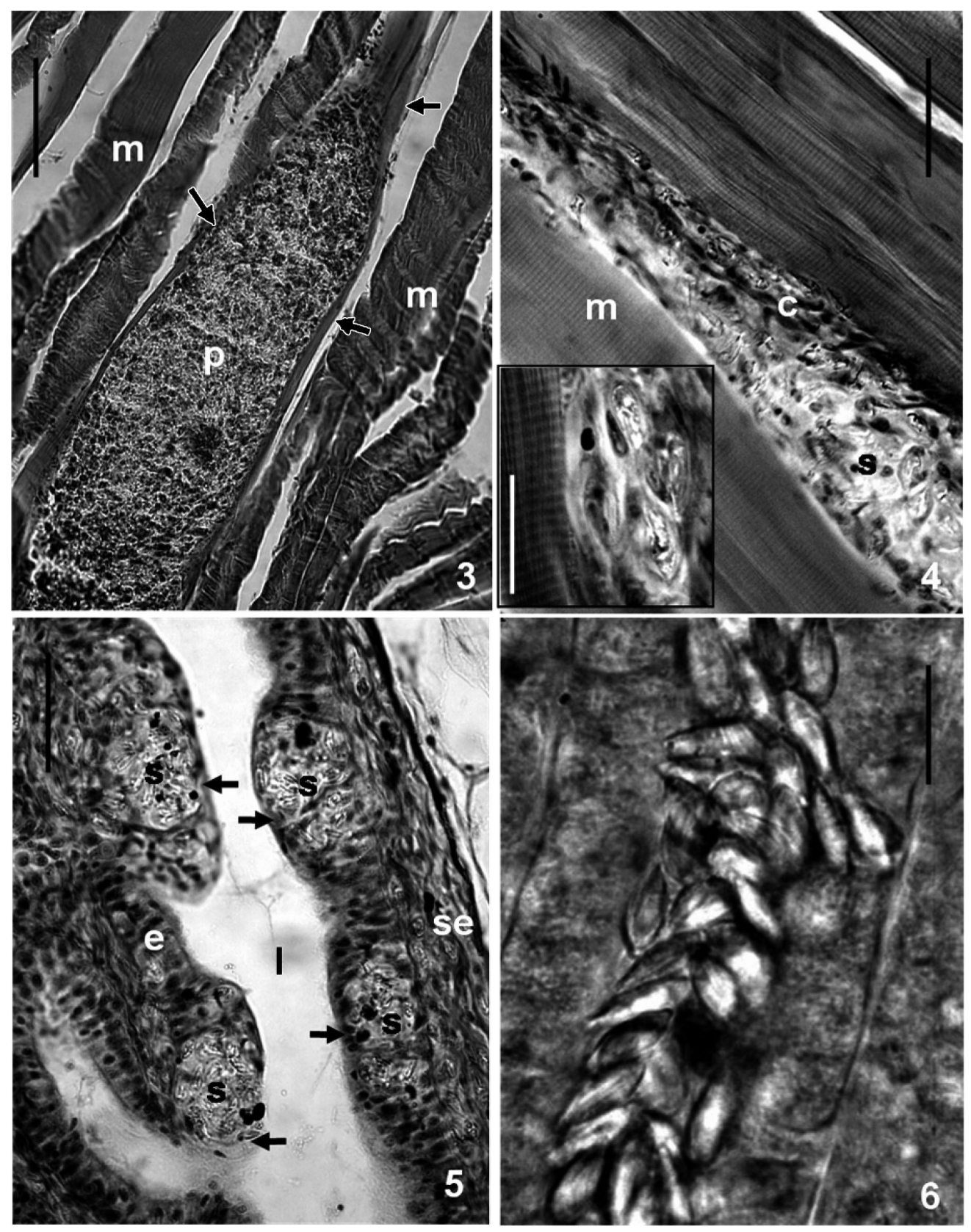

Figs. 3 to 6. Myxobolus leptobarbi sp. nov. Fig. 3. A plasmodium (p) of M. leptobarbi sp. nov. filled with spores among muscle cells (m) in Leptobarbus hoevenii. The plasmodium is still located inside the damaged infected muscle cell (arrows). Histological section with hematoxylin and eosin (H\&E) staining. Scale bar $=50 \mu \mathrm{m}$. Fig. 4. Spores (s) infiltrated by melanomacrophage cells (c) from a disrupted plasmodium are located free among the undamaged muscle cells $(\mathrm{m})$. Inset: enlarged part of the plasmodium with spores. Histological section with H\&E staining. Scale bar $=20 \mu \mathrm{m}$ for the picture and $10 \mu \mathrm{m}$ for the inset. Fig. 5. Small batches of mature spores (s) located in the propria layer of kidney channels covered by a thin flattened epithelium (arrows). Scattered spores are also found in the subepithelium (se). l = lumen of the channel, e = epithelium. Histological section with H\&E staining.

Scale bar $=50 \mu \mathrm{m}$. Fig. 6 . Spores filling the lumen of the urinary channel. Fresh preparation. Scale bar $=10 \mu \mathrm{m}$ 
culature, the host cells became damaged and spores isolated and engulfed by melanomacrophage cells were located free among undamaged muscle cells (Fig. 4). Spores belonging to this species were also found in the kidneys. These spores were mostly found in the wall of the urinary ducts, where they were disseminated in the connective tissue of the propria and submucosa or formed small spore batches bulging into the epithelium (Fig. 5). Above the accumulated spores, the otherwise columnar epithelium became flattened and spores entered and filled the lumen of the ducts (Fig. 6).

Remarks: By its spores of elongated shape and by the large number of filamental turns in the polar capsules, this species differs from most of the known Myxobolus spp. By its very long polar capsules it bears the closest resemblance to $M$. koi Kudo, 1919, a parasite of the common carp, but its spores are somewhat thicker and the genetic difference between the 2 hosts is rather large. In addition, $M$. leptobarbi is a parasite of the muscle cells, while $M$. koi infects the gill filaments. By its elongated, very long polar capsules and by the 9 to 11 coils of polar filaments, M. maruliensis described from Channid fishes in India by Sarkar et al. (1985) resembles $M$. leptobarbi sp. nov. but spores of $M$. maruliensis are more elongated and the host of the latter species belongs to a different fish family. The DNA structure presented in the present paper gives a further key to differentiating this species from other ones.

\section{Thelohanellus zahrahae sp. nov.}

Synonym: Thelohanellus sp. Siti Zahrah, Rokiah \& Sukerman, 2001.

Type host: Java barb Barbonymus gonionotus (Bleeker, 1850) syn. Puntius gonionotus Bleeker, 1850, (Cyprinidae). Local name: lampam jawa.

Type locality: Fish farm, Machang, Kelantan Province, Malaysia.

Site of tissue development: Gills. Large disporoblastic, elongated plasmodia $2-3 \times 0.2-0.4 \mathrm{~mm}$ in size with mature spores, were found in the gills inside the multilayered epithelium of the gill filaments.

Type material: Digitized photos of syntype spores and histological sections were deposited in the parasitological collection of the Zoological Department, Hungarian Natural History Museum, Budapest, coll. no. HNHM-70089. The 18S rDNA sequence of Thelohanellus zahrahae sp. nov. was deposited in GenBank under accession no. EU643622.

Prevalence of infection: $3 / 10$ in the $1 \mathrm{yr}$ old age group (fish 5 to $8 \mathrm{~cm}$ in size).

Intensity of infection: Moderate.

Etymology: The species is named after Dr. Siti
Zahrah Abdullah, fish parasitological researcher at Institut Penyelidikan Perikanan, Pulau Pinang, Malaysia.

Spores: The spores were large, drop-shaped (Figs. 1e,f \& 2c) both in frontal and sutural view. They tapered towards the anterior pole. The mean $( \pm \mathrm{SD})$ length of the spores was $23.8 \pm 1.33$ (range, 21.7 to 26.3) $\mu \mathrm{m}(\mathrm{n}=50)$, width $9.0 \pm 0.32$ (range, 8.5 to 9.4$) \mu \mathrm{m}$ ( $\mathrm{n}=50$ ), thickness $7.6 \pm 0.16$ (range, 7.5 to 7.9 ) $\mu \mathrm{m}$ $(\mathrm{n}=3)$. The single polar capsule was pear-shaped, slightly converging anteriorly. Capsules were $9.9 \pm$ 1.06 (range, 7.9 to 10.8$) \mu m$ long $(n=50)$ and $6.3 \pm$ 0.50 (range, 5.3 to 6.6$) \mu \mathrm{m}$ wide $(\mathrm{n}=50)$. Seven filament coils arranged slightly obliquely or perpendicularly to the capsule length were wound in the polar capsule. No intercapsular appendix was present. The tapered anterior end of the spore was compact. Width of the suture rim was about $0.5 \mu \mathrm{m}$. Sutural edge markings were not seen. A single binucleated sporoplasm with round iodinophilous vacuole was present. Mucous envelope was not found.

Molecular data: The DNA sequence of Thelohanellus zahrahae sp. nov. sample from Java barb does not fit that of the other Thelohanellus spp. available in GenBank (T. hovorkai, T. nikolskii), which showed 71 to $72 \%$ homogeneity with T. zahrahae (see Fig. 9 \& 10). The species most closely related to T. zahrahae sp. nov. in GenBank was Myxobolus hungaricus, with 85.8\% similarity.

Histology: Intrafilamental plasmodia were located alongside in the multilayered epithelium close to the basal part of the gill filaments. Only semi-mature plasmodia were found, filled with young spores and gamogonic stages (Figs. 7 \& 8).

Remarks: Several Thelohanellus spp. are known from cyprinid fishes. Tripathi (1952), who examined 3 known (T. seni, T. rohitae, T. catlae) and 3 new (T. mrigalaei, T. calbasui, T. gangeticus) Thelohanellus species in India, found great differences in the size of their spores. Of these species, T. rohitae with its 31 to $33 \mu \mathrm{m}$ spore length is larger, and T. seni, T. mrigalaei, T. calbasui and T. gangeticus are smaller than our species. Only 1 species, T. catlae, with its 19 to $24 \mu \mathrm{m}$ length, corresponds to the measurements of $T$. zahrahae sp. nov. Te (1984, cited by Arthur \& Te 2006) presumably found our species in the Java barb but identified it with T. catlae Chakravarthi et. Basu. In its morphology $T$. zahrahae sp. nov. resembles T. habibpuri, a species described by Acharya \& Dutta (2007) from Labeo rohita, a cultured cyprinid fish in India, but differs from it by its larger spores. Due to the poor quality of descriptions and inadequate drawings of the majority of Thelohanellus spp., proper identification on a morphological basis is difficult. However, knowing the strict host specificity and tissue tropism of these parasites (Akhmerov 1955, Molnár 2002), the occurrence of 

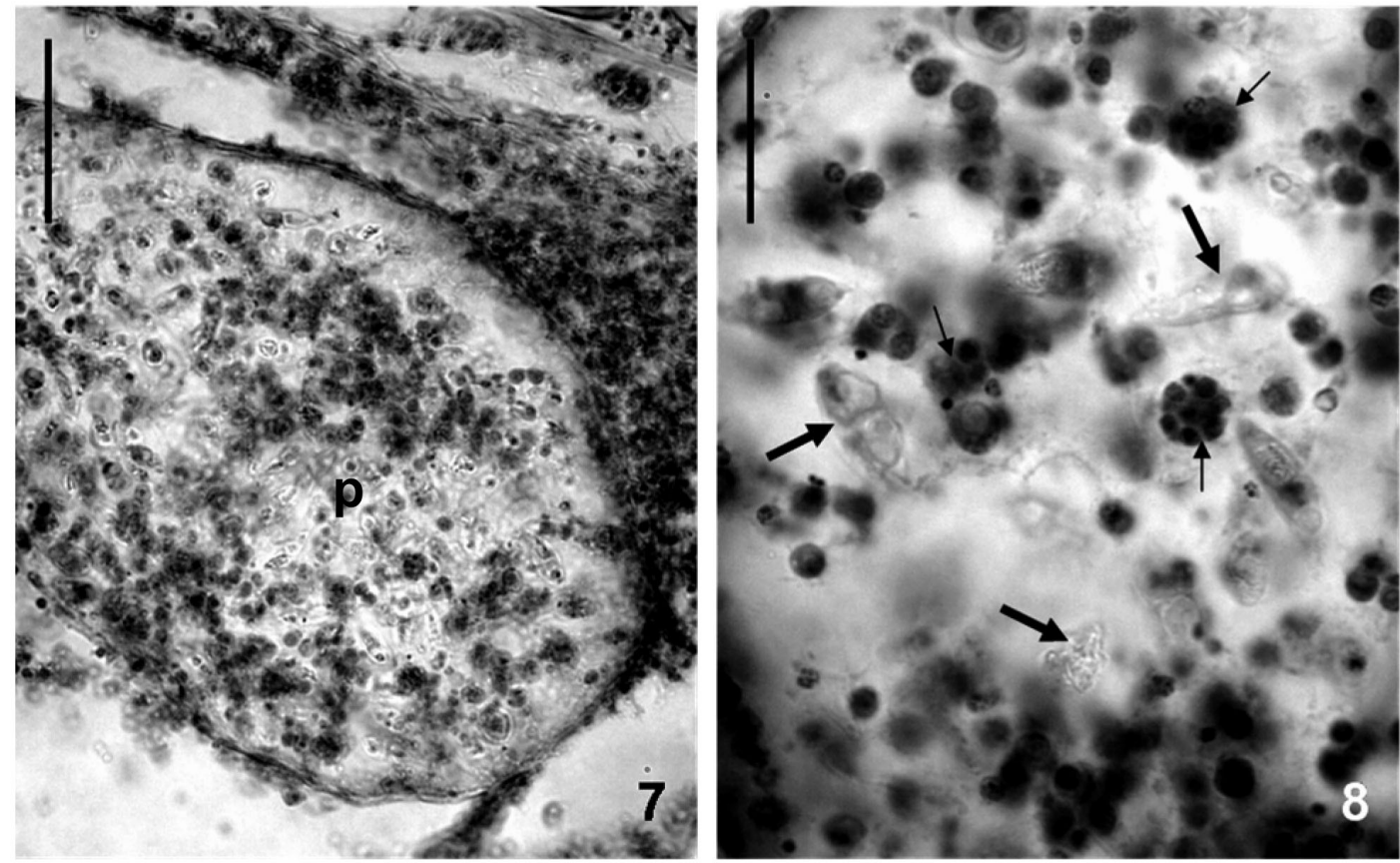

Figs. 7 \& 8. Thelohanellus zahrae sp. nov. plasmodium. Histological sections with H\&E staining. Fig. 7. Plasmodium (p) in the gills of Barbonymus gonionotus. Scale bar $=50 \mu \mathrm{m}$. Fig. 8. Enlarged part of a semi-mature plasmodium with spores (arrows) and trophozoites (small arrows). Scale bar $=25 \mu \mathrm{m}$

these organisms on systematically far-standing fishes is less feasible. Akhmerov (1955) wrote that different organs of the Amur wild carp were infected by different carp-specific Thelohanellus spp., and this strict host and tissue specificity was supported by Molnár (2002) as well. Zahrah et al. (1991) and Zahrah \& Shaharom (1992) reported heavy infections of the gills of Barbonimus gonionotus with a Thelohanellus sp. and gave detailed data on the occurrence, spore morphology and histological location of that species. We assume that they found the species described in the present study, as the data presented by Zahrah et al. (1991) on the host, location and dimensions of plasmodia and spores correspond to our data.

\section{Henneguya daoudi sp. nov.}

Type host: Three spot gourami Trichogaster trichopterus (Pallas, 1770), (Osphronemidae). Local name: sepat.

Type locality: Fish farm, Machang, Kelantan Province, Malaysia.

Site of tissue development: Gills. Only ruptured plasmodia with mature spores were found in the gills. The exact location of plasmodia could not be determined.

Type material: Digitized photos of syntype spores were deposited in the parasitological collection of the
Zoological Department, Hungarian Natural History Museum, Budapest, coll. no. HNHM-70090. The 18S rDNA sequence of Henneguya daoudi sp. nov. was deposited in GenBank under accession no. EU643625.

Prevalence of infection: $3 / 5$ of the fish 7 to $8 \mathrm{~cm}$ in size.

Intensity of infection: Moderate.

Etymology: The species is named after Daoud Harrison, husband of the second author, lecturer in the Language Department, University Darul Iman Malaysia, who actively helped the authors during the parasitological surveys of Malaysian fishes.

Spores: The spores (Figs. 1g-i \& 2d) were elongated with 2 straight or slightly bent caudal appendages, and elongated polar capsules located side by side. The spore wall was thin and smooth, composed of 2 equal valves. The suture was distinct in lateral view. The oral end of the spore body was blunt in frontal view and tapering in sutural view. The caudal end was rounded but continues in the caudal appendages. The mean $( \pm \mathrm{SD})$ spore body was $12.3 \pm 0.40$ (range, 11.4 to 12.8) $\mu \mathrm{m}$ long $(\mathrm{n}=50), 7.3 \pm 0.34$ (range, 6.7 to 7.6$) \mu \mathrm{m}$ wide and $5.3 \pm 0.30$ (range, 4.7 to 5.7$) \mu \mathrm{m}$ thick $(\mathrm{n}=50$ ). The 2 equal-sized polar capsules were drop-like, opening at the anterior end of the spore body. The polar capsules measured $5.9 \pm 0.40$ (range, 5.2 to 6.2 ) $\mu \mathrm{m}$ in length $(\mathrm{n}=50)$ and $2.7 \pm 0.36$ (range, 2.4 to 3.3$) \mu \mathrm{m}$ in width $(n=50)$. The polar filaments were coiled in 6 to 7 turns perpendicular to the long axis of the polar capsules. The length of the extruded filaments was $29.4 \pm$ 
3.99 (range, 27 to 31$) \mu \mathrm{m}(\mathrm{n}=50)$. The suture was 0.75 (range, 0.5 to 1$) \mu \mathrm{m}$ in width $(\mathrm{n}=50)$. The sporoplasm had a small round iodinophilous vacuole. In frontal view the $17 \pm 2.0$ (range, 15 to 20 ) $\mu \mathrm{m}$ long caudal appendages covered each other, while in lateral view they run straight and parallel to each other.

Molecular data: The sequence of Henneguya daoudi fits in the clade of many other Henneguya spp. on the phylogenetic tree. Its closest relative was Hennegoides mekongiensis showing $89 \%$ identity between their sequences, but based on only 435 aligned bp. Due to the shortness of the sequence of Hennegoides mekongiensis, however, this species cannot be seen on the phylogenetic tree. On the phylogenetic tree Henneguya daoudi is linked to an Australian marine species, Henneguya lesteri, with $83 \%$ identity between the 2 sequences (Figs. $9 \& 10$ ).

Remarks: Five Henneguya spp. (H. basifilamentalis, $H$. hemibagri, H. mystusia $H$. shariffi and $H$. shaharini)
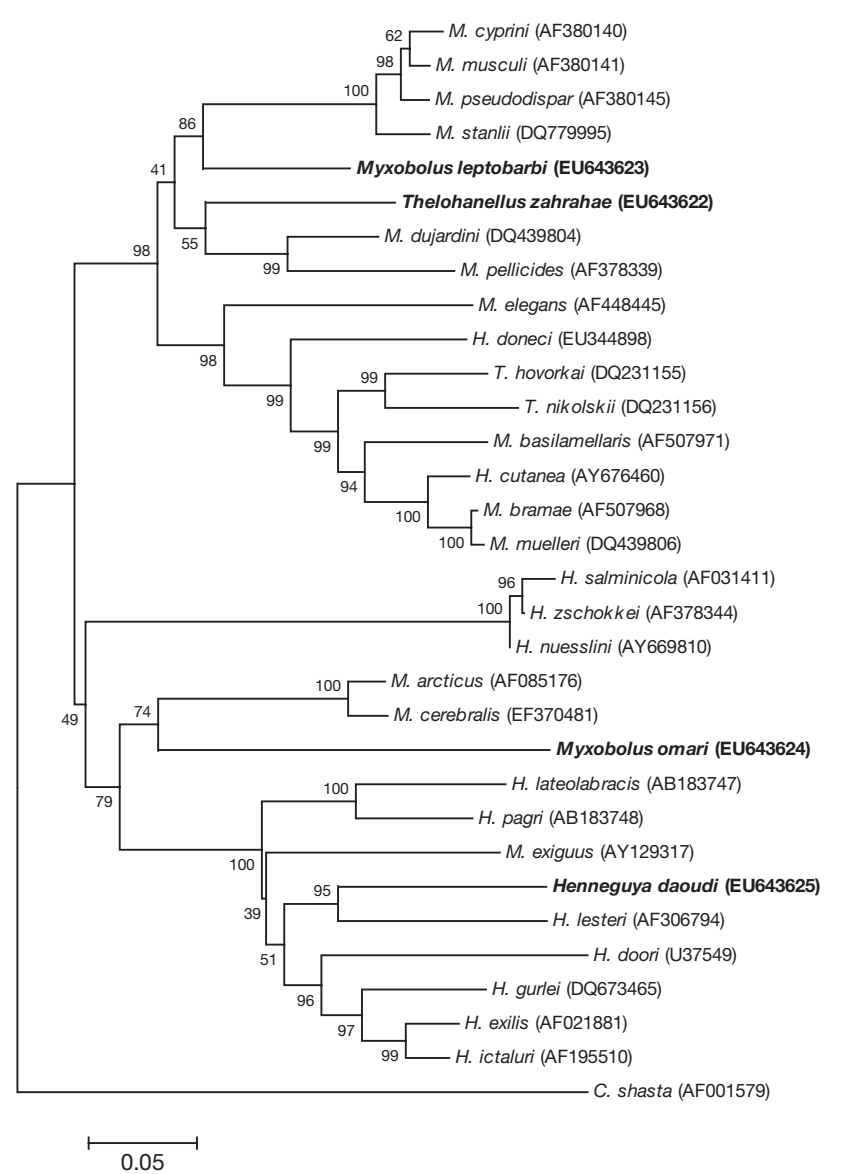

Fig. 9. Phylogenetic tree generated by neighbor-joining analyses of the 18S rDNA sequences of myxosporeans, rooted at Ceratomyxa shasta. Numbers at nodes indicate bootstrap confidence values (1000 replications). GenBank accession numbers are given in parentheses. Myxosporeans examined in the present study are in bold

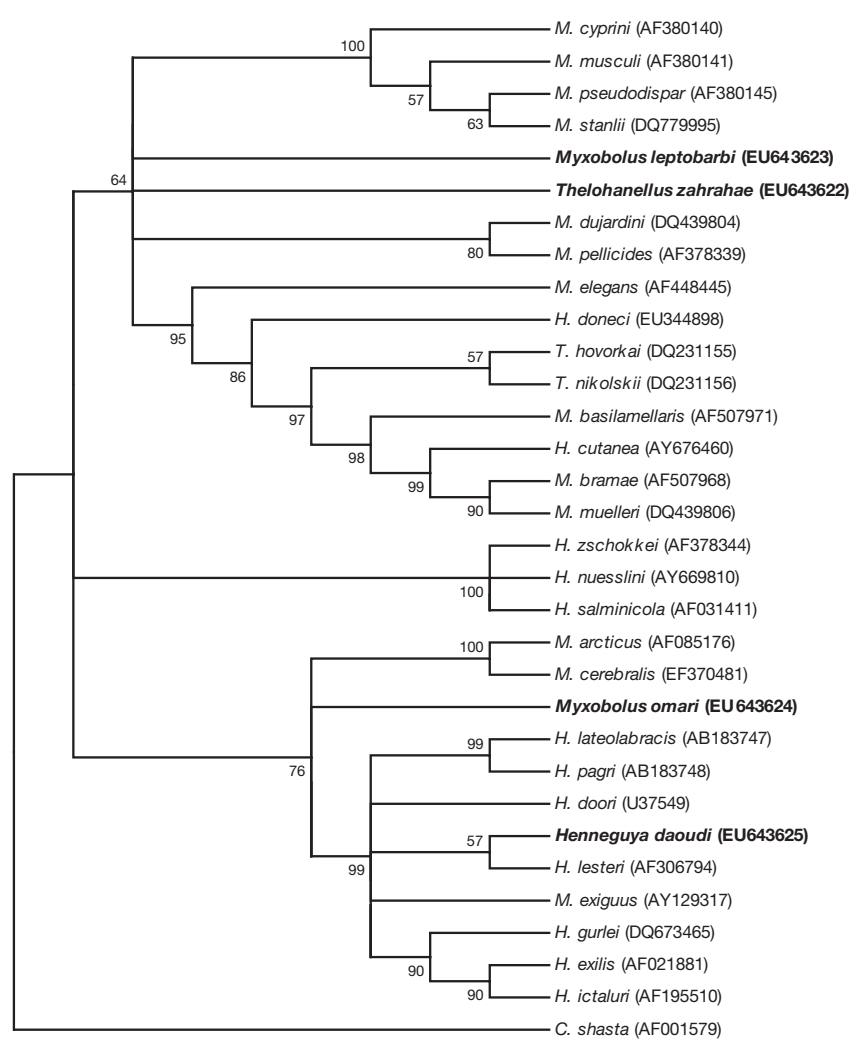

Fig. 10. Phylogenetic tree generated by maximum parsimony of the 18S rDNA sequences of myxosporeans, rooted at Ceratomyxa shasta. Numbers at nodes indicate bootstrap confidence values (100 replications). GenBank accession numbers are given in parentheses. The branches under bootstrap value 50 were cut off. Myxosporeans examined in the present study are in bold

have been reported from Malaysia (Shariff 1982, Molnár et al. 2006a,b). The spores of $H$. daoudi sp. nov. resemble those of $H$. shariffi, $H$. mystusia and $H$. shaharini by their size but differ from the latter by their blunt-shaped anterior ends and less elongated polar capsules. This new species also differs from $H$. shariffi and $H$. mystusia by its longer or shorter caudal extensions, respectively. In addition to the morphological differences, this parasite was collected from a fish which is genetically distant from other fishes known to be infected by Henneguya spp.

\section{DISCUSSION}

During this study, infections with 4 new myxosporeans (2 Myxobolus spp., Henneguya sp. and Thelohanellus sp.) were found in cultured Malaysian fishes. Myxobolus spp. infecting fishes of the Tasik Kenyir Water Reservoir are described in another paper (Székely et al. 2009). M. leptobarbi sp. nov. was found in the mus- 
cle of the mad barb, a favorite cyprinid sport and food fish cultured in several pond farms of Malaysia. The intensive infection found in mad barb suggests that the parasite might have pathological significance during the culturing of this fish species, especially in 1st yr stocks. A similar heavy infection by M. pseudodispar in the muscles has been reported in $1 \mathrm{yr}$ old roach of Lake Balaton, Hungary and in some British freshwaters. In roach, intensive infection with $M$. pseudodispar negatively affected the survival of the fish (Molnár et al. 2001, 2002, Longshaw et al. 2003). Besides the common occurrence of plasmodia in the muscle cells, large numbers of spores were found in the kidney, which indicates that spores might be released from the fish body through the urinary ducts. In studying $M$. cyprini and M. pseudodispar, Molnár \& Kovács-Gayer (1985) and Baska (1987) proved that a large number of spores of muscle-dwelling Myxobolus spp. leave the fish via the bloodstream through the skin, gills, gut and kidneys. It is not a surprise, therefore, that the DNA sequences of spores collected from the muscles corresponded to those of spores in the kidneys. On the other hand, the occurrence of spores in the kidney was rather uncommon. Besides spores filling the lumen of the renal tubules, spores were also found accumulated under the tubular epithelium in large batches. This latter location suggests that the spores transmitted to the kidney by the bloodstream do not necessarily get into the urinary channels through the glomeruli of the Bowman's capsules but some of them might be carried into the capillary-rich connective tissue of the renal tubules from where the spores break through the damaged epithelium into the lumen of channels, from where they are excreted via the urine. A similar location and manner of development is feasible for $M$. omari sp. nov. in the sutchi catfish. From that fish species, only 2 Myxobolus spp., M. baskai and M. pangasii, have been known until now (Molnár et al. 2006a). The former species has a specific location in the gills, while the latter infects the spleen. The characteristic wide-shaped spores of $M$. omari sp. nov. resemble those of $M$. artus Akhmerov, 1960 described from the Amur wild carp in the Far East.

Thelohanellus zahrahae sp. nov. might also have pathological significance in fish culture. Zahrah et al. (1991) and Zahrah \& Shaharom (1992), who studied this species and identified it only as 'Thelohanellus sp.', found heavy infections among experimental fish stocks. The common occurrence of this species in Barbonymus gonionotus in southeast Asia is rendered probable by the fact that this species was found but improperly identified as T. catlae by Te (1984, cited by Arthur \& Te 2006) also in Vietnam.

Henneguya spp. belong to the most common parasites of fishes. In a synopsis on this genus, Eiras (2002) reported the existence of 146 Henneguya spp., described mostly from fishes of the temperate climate zones. Henneguya spp. and Hennegoides spp. seem to be the most common parasites in non-cyprinid fishes in other parts of southeast Asia (Chakravarty 1939, Lalitha-Kumari 1965, 1969, Ky 1971, Sarkar et al. 1985, Lom et al. 1991, Chen \& Ma 1998, Molnár et al. 2006a,b, Te 1984, cited by Arthur \& Te 2006). Therefore, the occurrence of Henneguya daoudi sp. nov. on the gills of Trichogaster trichopterus is not surprising.

Of the species studied in the present study, neither Myxobolus spp. nor Thelohanellus sp. showed close affinity in their DNA sequence to the species deposited in GenBank, because the sequences of myxobolid species are mostly from Europe, North America or China. However, M. leptobarbi can be found next to European muscle-infecting species. $M$. omari differs from the closest Myxobolus species so much that any relevant conclusion on its phylogeny cannot be drawn. The position of T. zahrahae is not among the other Thelohanellus spp., which are also from European regions. This kind of polyphyly occurs in the case of Henneguya spp. There are different Henneguya clades among the Myxobolus spp. separated form each other. $H$. daoudi could be on the main Henneguya branch next to $H$. lesteri.

Acknowledgements. The authors thank the staff of AQUATROP, UMT for their help in laboratory work and fish collection. We are grateful to G. Ostoros for the histological work and the drawings. The work was financially supported by the University Malaysia Terengganu and partially by the Hungarian Research Grant OTKA K 71837.

\section{LITERATURE CITED}

Acharya S, Dutta T (2007) Thelohanellus habibpuri sp. nov. (Myxozoa: Bivalvulida) from the tropical freshwater fish rohu, Labeo rohita (Hamilton-Buchanan, 1882) in West Bengal, India: light and electron microscope observations. Anim Biol 57:293-300

Akhmerov AH (1955) Ways of the origin of Myxosporidia species of the genus Thelohanellus Kudo from Amur wild carp. Dokl Akad Nauk USSR 105:1129-1132

Ang KJ (1990) Status in aquaculture in Malaysia. In: Joseph MM (ed) Aquaculture in Asia. Asian Fisheries Society, Indian Branch, Mangalore, p 265-279

Arthur JR, Te QB (2006) Checklist of the parasites of fishes of Viet Nam. FAO Fish Tech Pap 369/2. FAO, Rome

Baska F (1987) Histological studies on the development of Myxobolus pseudodispar Gorbunova, 1936 in the roach (Rutilus rutilus). Acta Vet Hung 35:251-257

Chakravarty MM (1939) Studies on Myxosporidia from the fishes of Bengal, with a note on myxosporidian infection in aquaria fishes. Arch Protistenkd 92:169-178

Chen QL, Ma CL (1998) Myxozoa, Myxosporea. Fauna Sinica. Science Press, Beijing, (in Chinese with English abstract)

> Eiras JC (2002) Synopsis of the species of the genus Henneguya Thélohan, 1892 (Myxozoa: Myxosporea: Myxobolidae). Syst Parasitol 52:43-54

Ky H (1971) Some freshwater myxosporean species from 
North Vietnam. Acta Protozool 8:283-298 (in Russian with English abstract)

Lalitha-Kumari PS (1965) On a new species of Henneguya (Protozoa: Myxosporidia) from Indian freshwater fish, Ophiocephalus gachua. Riv Parassitol 26:79-84

Lalitha-Kumari PS (1969) Studies on parasitic protozoa (Myxosporidia) of freshwater fishes of Andhra Pradesh, India. Riv Parassitol 30:154-225

Lom J, Tonguthai K, Dykova I (1991) Hennegoides longitudinalis n. gen. n. sp., a myxosporean parasite of Osphronemus gourami from Thailand. Dis Aquat Org 11:143-145

Longshaw M, Frear P, Feist SW (2003) Myxobolus buckei sp. nov. (Myxozoa), a new pathogenic parasite from the spinal column of three cyprinid fishes from the United Kingdom. Folia Parasitol 50:251-262

Molnár K (2002) Differences between the European carp (Cyprinus carpio carpio) and the coloured carp (Cyprinus carpio haematopterus) in susceptibility to Thelohanellus nikolskii (Myxosporea) infection. Acta Vet Hung 50:51-57

Molnár K, Kovács-Gayer E (1985) The pathogenicity and development within the host fish of Myxobolus cyprini Doflein, 1898. Parasitology 90:549-555

Molnár K, Székely C, Csaba G, Láng M, Majoros G (2001) Investigation of pathology and veterinary aspects of Lake Balaton fishes. In: Mahunka S, Banczerowski J (eds) Results of Balaton research in the year 2000. MTA, Budapest, p 158-166 (in Hungarian)

Molnár K, Székely C, Csaba G, Láng M, Majoros G (2002) Investigation of pathology and veterinary aspects of Lake Balaton fishes. In: Mahunka S, Banczerowski J (eds) Results of Balaton research in the year 2001. MTA, Budapest, p 160-190 (in Hungarian)

Molnár K, Székely C, Mohamed K, Shaharom-Harrison F (2006a) Myxozoan pathogens in cultured Malaysian fishes. I. Myxozoan infection of the sutchi catfish. Dis Aquat Org 68:209-218

Editorial responsibility: Dieter Steinhagen,

Hannover, Germany
Molnár K, Székely C, Mohamed K, Shaharom-Harrison F (2006b) Myxozoan pathogens in cultured Malaysian fishes. II. Myxozoan infections of redtail catfish Hemibagrus nemurus in freshwater cage cultures. Dis Aquat Org 68:219-226

Ong KS (1993) Aquaculture development in Malaysia in the 1990's. Risalah Perikanan Bilangan 51. Department of Fisheries, Ministry of Agriculture, Kuala Lumpur

Sarkar NK, Mazumder SK, Pramanik A (1985) Observation of 4 new species of myxosporidia (Myxozoa) from channid (Ophiocephalid) fishes of West Bengal, India. Arch Protistenkd 130:289-296

Shariff M (1982) Henneguya shaharini sp. nov. (Protozoa: Myxozoa), a parasite of marble goby, Oxieleotris marmoratus (Bleeker). J Fish Dis 5:37-45

Székely C, Shaharom-Harrison F, Cech G, Ostoros G, Molnár K (2009) Myxozoan infections in fishes of the Tasik Kenyir Water Reservoir, Terengganu, Malaysia. Dis Aquat Org 83:37-48

Tripathi YR (1952) Studies on parasites of Indian fishes. Protozoa: Myxosporidia together with a check-list of parasitic protozoa described from Indian fishes. Rec Indian Mus 50: $63-88$

Zahrah SA, Shaharom FM (1992) A study of Piscionoodinium pillulare and Thellohanellus sp. infection in gills of Puntius gonionotus (Bleeker). In: Ho Y, Vidyadaran MK, Abdullah N, Jainudeen MR, Bahaman AR (eds) Proc Natl Intensification of Research in Priority Areas Seminar II, 6 to 11 Jan 1992, Kuala Lumpur. Ministry of Science, Technology and Environment, Kuala Lumpur, p 285-286

Zahrah SA, Rokiah AL, Sukerman S (1991) Morphological characteristics of Thellohanellus sp. in gills of $P$. gonionotus (Bleeker) and its prevalence. In: Chong LP (ed) Proc Fish Res Seminar. 30 Sep to 2 Oct 1991, Penang. Department of Fisheries, Ministry of Agriculture, Kuala Lumpur, p 384-392

Submitted: June 11, 2008; Accepted: September 22, 2008 Proofs received from author(s): December 5, 2008 